\title{
Community - Based Ecotourism: Trends and Prospects in Tamil Nadu
}

\author{
Dr. A. Apsara Saleth Mary* \\ Faculty, Centre for Tourism and Hotel Management, Madurai Kamaraj University, Palkalai Nagar, Tamil \\ Nadu, India
}

*Corresponding Author: Dr. A. Apsara Saleth Mary, Faculty, Centre for Tourism and Hotel Management, Madurai Kamaraj University, Palkalai Nagar, Tamil Nadu, India

\begin{abstract}
Community-Based Ecotourism ventures are environmentally sensitive initiatives, which also aim to ensure that members of local communities have a high degree of control over the activities taking place, and a significant proportion of the benefits accrue to them. A community-based approach to Ecotourism recognizes the need to promote both the quality of life of people and the conservation of resources. The changing demands of tourists for 'natural' and 'exotic' environments have created new tourism products in developing countries. Community-Based Ecotourism (CBET) is one such segment which is much in demand these days. This particular form of tourism has been considered in this study to know about the awareness that the people have and to analyze the trends in CBET and its impact on fulfilling the objectives. The results show that people are aware about this concept and are also experiencing this in Tamil Nadu, but most of the CBET ventures are publicly owned and managed and hence fewer benefits are encashed by the local community of the region.
\end{abstract}

Keywords: Community-based, Ecotourism, Environment, Natural, Exotic.

\section{INTRODUCTION}

Ecotourism was first defined as, a form of travelling to relatively undistributed or uncontaminated natural areas with the specific objective of studying, admiring, and enjoying the scenery and its wild plants and animals, as well as any existing cultural manifestations (both past and present) found in these areas (Ceballos - Lascurain, 1987). Further to this, The International Ecotourism Society (TIES, 1990), defined that "Ecotourism is responsible travel to natural areas that conserves the environment and improves the well-being of local people". Based on this definition, the basic principles of ecotourism was developed which details that the purpose of Ecotourism is uniting conservation, communities, and sustainable travel.

According to WWF International, community-based ecotourism takes the social dimension of ecotourism a stage further, by developing "a form of ecotourism where the local community has substantial control over, and involvement in, its development and management, and a major proportion of the benefits remain within the community."

Community-Based Eco-tourism initiatives are environmentally sensitive, which aim to ensure that members of local communities have significant control over the activities that take place, and they receive benefits from these activities. A community based approach to ecotourism understands the need to promote both the quality of life people and the conversation of resources.

Authors have suggested that the term Community-Based Ecotourism ventures should be used to distinguish those initiatives which are environmentally sensitive, but which also aim to ensure that members of local communities have a high degree of control over the activities taking place and a significant proportion of the benefits occur to them (Liu, 1994, Ceballos - Lascurain, 1996). A community based approach to Ecotourism recognizes the need to promote both the quality of life of people and the conversation of resources.

Environmental, socio-cultural and business concerns are becoming increasingly interlinked. This requires management thinking that goes beyond the 'green' agenda and beyond an approach to 
Corporate Responsibility which devolves environmental or social considerations from the core business model. (David Scowsill, President cum CEO, World Travel \& Tourism Council).

\section{LITERATURE REVIEW}

In the context of sustainable tourism development, the importance of CBT has clearly been recognized over the past two decades. Community based conservation and people's participation have become part of the conventional rhetoric and more attention is being paid to this approach on the ground by international and national conservation organizations (Pimbert \& Pretty, 1997). While mass or mainstream tourism attracted trenchant criticism as a shallow and degrading experience for developing countries, so-called "alternative" forms of tourism have been viewed much more benevolently and few critiques have emerged (Ryan, 2002). As a particular alternative forms of tourism, CBT suggests a symbolic or mutual relationship where the tourist is not given central priority but becomes an equal part of the system (Wearing \& McDonald, 2002).

A study on Kerwa Van Vihar National Park Catchments done in 2003 concluded that with organized planning and implementation, ecotourism can make a breakthrough for the conservation and economic development of the area. As much as the local people are aware, sensitive and encouraging about the tourism ventures, there is a strong disliking for non-environmental tourist behaviors of contributing pollution. The paper also states that there is need for capacity building for providing opportunities to local people for starting business at small scale level. (Bhattacharya, Banerjee and Saksena, 2003).

CBT is intended to empower people, the representations deployed in constituting the targeted "communities", be they imagined or real, remain largely unexamined.

International organizations concerned CBT as a mean for development by declaring the year 2002 as the International Year of Ecotourism and also carried out a detailed study of the effect of CBT to poverty reduction by The United Nations (UNDESA, 1999). The World Bank, arranged a work shop on CBT in 2000. CBT was also included in national development strategies of several countries like South Africa and Namibia.

Kerala was the first state in India to have enacted a Tourism Conservation, Preservation and Trade Bill to regulate-related activities in the state. The state also took up the task improving wayside facilities, boat terminals and jetties. In addition, it built a good waste disposal system for the backwaters. Commenting on this, T. Balakrishnan, Kerala Tourism Secretary said, "The first step is concessional power tariff for approved star hotels, amusement parks, motels, restaurants, ropeway tourist centers and others. This would be followed by improving other basis infrastructures projects like roads and wayside facilities. All the projects have to conform to the stat's long term goal". As a result of the above initiatives, international tourist arrivals in the state increased from 69,000 in 1991 to 0.21 million in 2000 , while domestic tourists numbered 5 million during the same year. The state earned around Rs.5 billion in total direct revenues from tourism in 2001-02, which is highly appreciable. (Chandra, Global Eco Tourism-Codes, Protocols and Charters, 2003).

The tourism and recreation industry is at a cross roads in its development. Being one of the largest industries of world, it is increasingly confronted with arguments about its sustainability and compatibility with environmental protection and community development. (Sehgal, Gaur, 2006).

Balint, 2006, urges that results will improve if project leaders pay closer attention to four development indicators, that is, rights capacity, governance and revenue, that are often taken for granted or considered beyond the scope of local conservation projects. Community-based conservation has a role to play in a broad pluralistic approach to biodiversity protection; it is governance that stars from the ground up and involves networks and linkages across various levels or organization. (Berkes, 2007).

Sharma \& Kamboj (2012) in their research on Responsible Tourism, stressed upon the need for awareness and education at all levels, initial, secondary, community and professional. Continuing professional development education is more likely to have an immediate impact on the sustainable management of tourism in destinations. Moreover, use of education to build the transferable technical capacity of all stakeholders is required. There is also the need to educate tourists, the intermediaries in the transit route, and generating markets on local sociocultural, economic and environmental issues in the market and the destination; likewise educating the communities on the cultures of the visitors. 


\section{OBJECTIVES OF THE RESEARCH}

The concept of Community-based ecotourism is on a fast rise in the developing countries for past few years and hence developments have also taken place in this regard. Therefore the present research work is undertaken with the following objectives:

- To know about the awareness that the people have about the concept of CBET in Tamil Nadu.

- To know the prospects of CBET in Tamil Nadu and

- Its impact on the local community of the region.

\section{RESEARCH METHODOLOGY}

To fulfill the objectives of the present research work, personal visits to few destinations in Tamil Nadu were made (Kodaikanal. Ooty, Theni, Coimbatore and Tirunelveli) between year 2016 and 2017. During these visits interviews and discussions ware made with the stakeholders as well as the local residents who were engaged in the CBET ventures to make the study more practical, an online questionnaire was also prepared and was emailed to prospective respondents from January 2017 to Dec. 2017 in Tamil Nadu. The data has been collected from 50 responses that were received and analyzed.

\section{COMMUnity-BASED ECOTOURISM}

CBT is tourism that takes environmental, social and cultural sustainability into account. It is management and owned by the community, for the community, with the purpose of enabling visitors to increase their awareness and learn about the community and local ways of life.

Community Based Tourism programs are development based around special elements of local lifestyle, culture, people and nature that community members feel product of and choose to share with guests.

Guests have an opportunity to experience and learn about the community and the environment through fun, "hands-on" activities lead by local community guides comprises of jungle trekking, fishing, birds watching, natural dying, learning to cook local traditional dishes, etc.

Tourism services and activities are planned and managed by local people, working together in a "CBT Group". The programs are designed to support local community and the environment, to build local skills, and to distribute opportunities fairly.

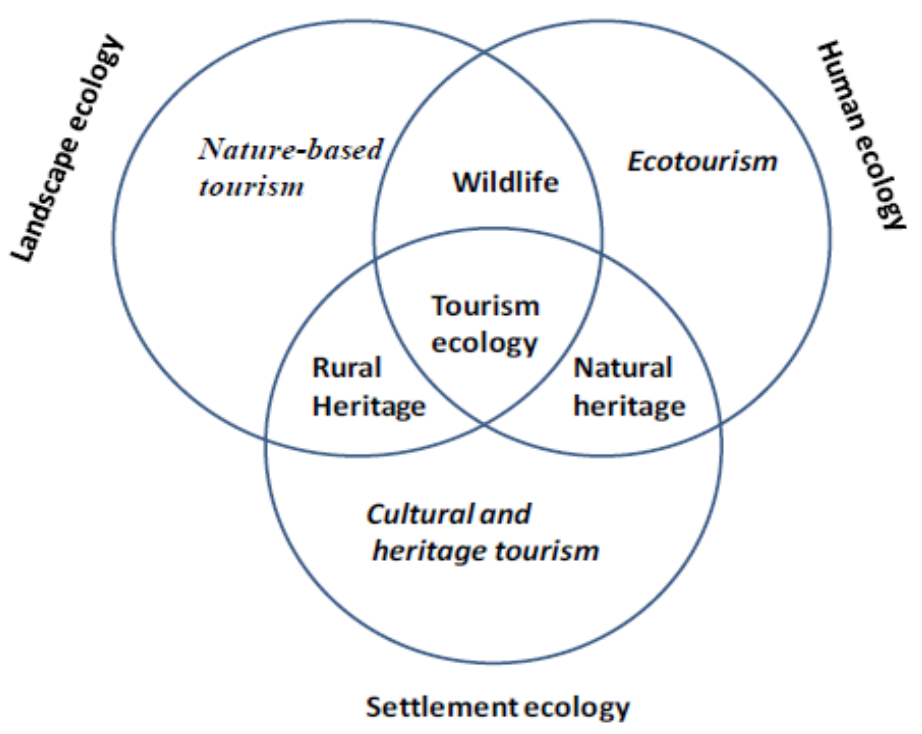

Figure1: Tourism Ecology

Source: David 2009

Guests experience and learn about rural people, their lives, cultures, and inter-relationship with the natural world. In community-based tourism, activities are developed and operated, for the most part, 
by local community members, with their consent and support. An important of this type of tourism is that a share of the revenues is enjoyed by the community in one way or another. This may include revenue which goes to co-ops, joint ventures, community associations, businesses that widely employed local people, or to a range of entrepreneurs starting or operating small-and medium-sized enterprises.

Community-based tourism imparts respect and concern for the natural heritage and environment.

Accommodation which is the major tourism component yields higher cost and benefits. There is always a price hike in developing tourism infrastructure. Modern lifestyle and standards are constantly changing the needs and demands of the guests and thus it reflects in the tourism infrastructure development. Concept of Home Stay Scheme is being implemented in many states across India with the objective to popularize tourism in rural areas. The objective is to provide employment and economic value to the local population and reasonable yet good quality accommodation at reasonable rates to tourists.

This concept of Home Stays has succeeded in diverting tourists from the popular urban tourist destinations to new and untapped places. This has enabled the state governments to promote new tourist destinations and provide alternative source of income to the communities. (Gangotia, 2013).

Tourism is one such element which if developed in a planned manner can create wonders for the society and if developed in unplanned manner can create hazards for the community, the guests and the environment. The recent examples are Uttarakhand disaster and a fire tragedy in Kurangani Hills in 2018 appropriately proves the point.

India the objectives of tourism development are to bring understanding among people, creating employment opportunities and bring about socio-economic benefits to the community particularly in the interior and remote areas and to strive toward balanced and sustained development and preserve enriched and promote cultural heritage.

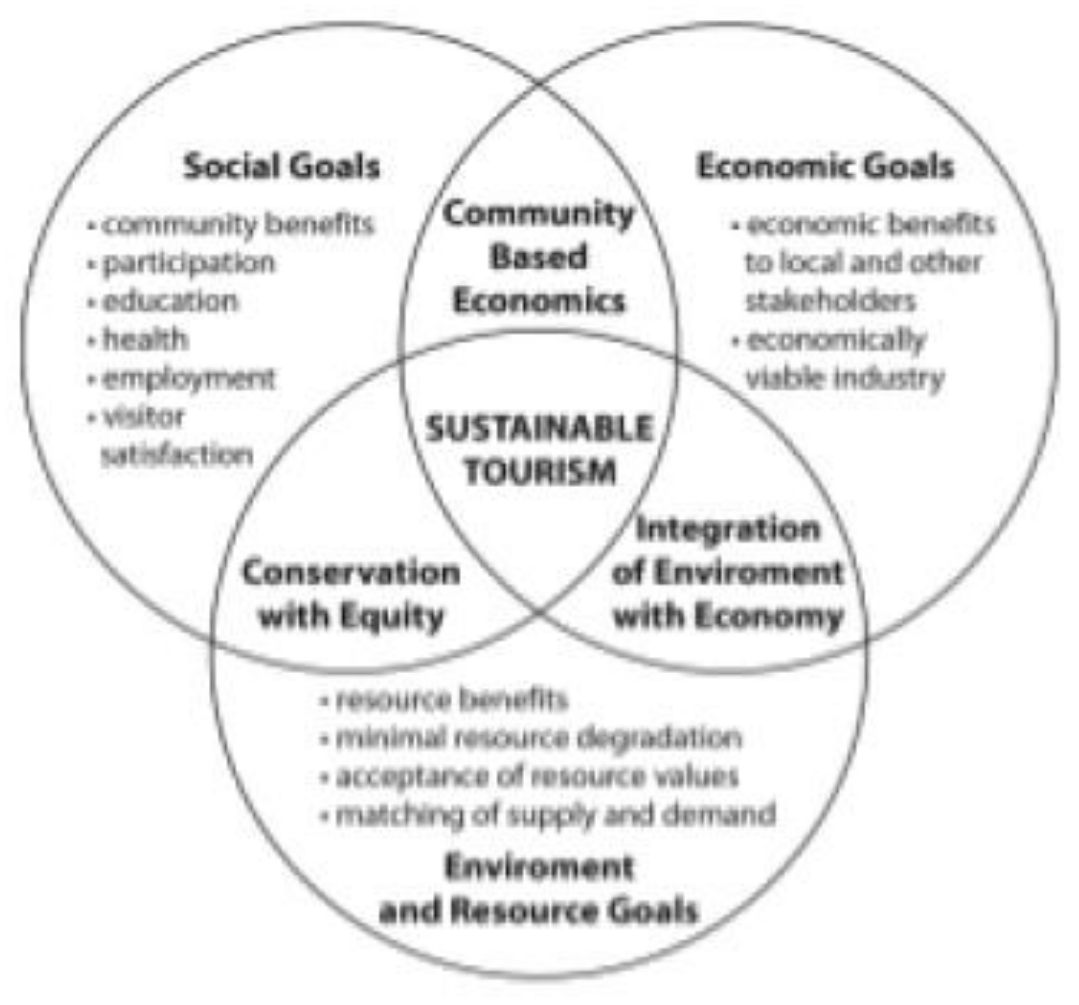

Figure2: A model of Sustainable Tourism Values and Principles, Adapted from Hall, Jenkins and Kearsely (1997) (Brograard, 2010).

\subsection{Initiatives in Community Based Ecotourism}

Tamil Nadu Government: The Tamil Nadu government released an ecotourism policy in 2017, which envisages a major role for local communities. Community-based Ecotourism was one of the guiding principles on which the development of ecotourism in the state will be based. 
The Forest Department is the Nodal Department for implementing the policy and created SEB (State Ecotourism Board) to take policy decisions for promotion and development of ecotourism.

At the District level Ecotourism Management Societies (ETMS) is established to promote, manage and regulate ecotourism sites. ETMC's have been created by the Government of Tamil Nadu, wherein, destinations that have an Eco-tourism as a product are run by the Local Community, through the Joint Forest Planning and Management (JFPM). This involves the formation of Village Forest Committees (VFCs) to formally enter into partnership agreements with the forest department for planning and implementing various forest protection, conservation and development programmes. This is done based on a Management Plan (MP) that the villagers evolve in collaboration with the forest department and various government and non-government agencies after due stakeholder consultations. The Ecotourism policy of the Government of Tamil Nadu, Forest Department, has proposed for measures that will focus on the community participation to enhance not only livelihood options but also management of the ecotourism destinations locally.

Tamil Nadu Forest Department has formulated a project called Tamil Nadu Biodiversity Conservation and Greening Project (TBGP) aided by the Japan International Cooperation Agency (JICA); it also ensures ecologically sustainable development initiatives by promoting community participation in eco development, tribal development and eco tourism.

The coordination and networking with the State Forest Department, Tamil Nadu

Tourism Development Corporation and Hindu Religious and Charitable Endowments

Department for management, promotion and marketing of ecotourism destination and products are necessary for development of sustainable ecotourism.

\subsection{Volunteer}

Volunteers are always welcome and are being trained under Tamil Nadu Innovation Initiative (TANII) for Wildlife rescue and release. Some of the important activities for the volunteers are as follows:

- Study of Flora and Fauna of the Area.

- Awareness Generation on Sensitive Conservation Issues.

- Promotion of Community-Based Ecotourism in the Area.

\subsection{Keystone Foundation}

The Keystone Foundation, since 1993 has been working in the Nilgiri Biosphere Reserve (NBR) with indigenous communities on improving their lives, livelihoods, and maintaining their unique cultures. Keystone maintains the principles of eco-development through a holistic approach towards livelihoods, conservation, and enterprise, and aims to support and empower indigenous groups to realize a better future, for many generations to come. As an eco-tourism initiative in Kotagiri range, Keystone is partnering with the Tamil Nadu Forest Department. The initiative is being implemented under the aegis of the Tamil Nadu Biodiversity Conservation and Greening Project (TBGP) and it is an effort to use ecotourism as a strategy to further community participation in conservation activities. The Keystone mantra is "small is effective/small is global".

\section{BENEFITS OF CBET}

\section{- Builds Community Strength and Unity}

The local community is involved in carrying out the day to day operations for delivering the services to the guests. Working towards the common goal enhances the community strength and unity.

\section{- Community-Based Tourism Products}

In order to provide a village experience to tourists by guiding them through real life situations in hinterlands and thereby distributing economic benefits of tourism directly to the community, tour packages are developed. These packages are popular among tourists and the state tourism websites are promoting these. The members of the community participating in the package by showing / demonstrating their activities receive fixed amounts from the package - price realized. These packages creates close interaction between the community and the visitors. 


\section{- The Empowerment of Women}

Community based tourism plays an important role in empowering local women. It calls for community participation with women's active role in decision-making, benefits sharing, pride in traditional skills; environment care, systemic ownership and sustainable management of the process are among the principal intended outcomes. The Government of India-United Nations Development Program's Rural Tourism Project aims to empower women in tourism.

\section{- Strengthening Community Pride}

Community based tourism encourages the locals to share the culture of village life that has existed for centuries with tourists from urban areas. From local arts and crafts to recipes, songs and dance, guests experience the vibrancy and joy of rural life. This in turn strengthens the pride among local population for their culture.

\section{- Passing on Traditional Skills and Knowledge between Generations}

While visiting rural areas, tourists experience local traditions and consume local products respectively. As these destinations become popular, the demand for such traditional products increases. In many cases this has helped in reviving arts and crafts as people pass on their skills and knowledge to their future generations to fulfill the increasing demands for such products. People also start taking pride in their heritage-clothing, food, customs and beliefs, lifestyle, building technologies etc.

\section{- Increased Hygiene and Safety Awareness}

The Endogenous Tourism Project is a collaborative effort between the Ministry of Tourism (MoT) and United Nations Development Programme (UNDP) initiated in 2003 and being implemented at 36 sites across the country. Infrastructure development in the ETP falls into three broad categories. First those that had direct linkage to tourism (accommodation, restaurants, tourist information / interpretation centres), second those that are geared to overall village development and indirectly benefiting tourism (toilets, pavements, footpaths, street lighting) and third was an aspect of convergence of various schemes for the village so as to provide basic facilities \& services and civic amenities in which they lacked. The capacities of community members were built by conducting training on varied issues - awareness, tourism linked skills and livelihood, alternative livelihood and institutional management. (Equation 2008)

\section{- Economic Contributions}

Tourism has always been a great contributor to the economic growth of the region. In order to determine the success of any project, it is important to assess the distribution of economic wealth amongst its stakeholders. It is important that these gains are regular and reliable.

\section{FINDINGS AND DISCUSSIONS}

To fulfill the objectives of the present research work, an online questionnaire was prepared and distributed. The questions were objective and open ended to ensure to more participation and ease of filling it. The respondents were both male and female and most of them were students, academicians, hospitality professionals and entrepreneurs, who fell in the age group of 20-30 year old.

The findings of some of the questions are discussed below:

1. From the graph mentioned below it is clear that more than 95 percent of respondents were aware about the concept of CBET in Tamil Nadu.

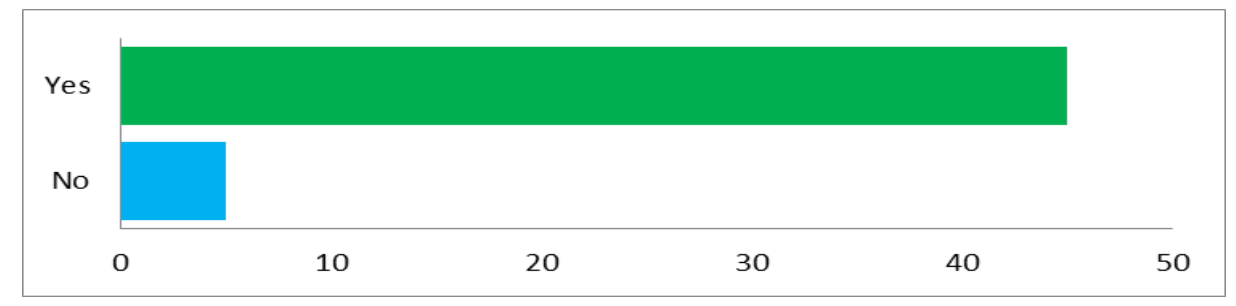

2. When asked about the source of awareness, multiple options were given to respondents and the results show that maximum respondents gained awareness about this concept from word of mouth and further by reading magazines. 


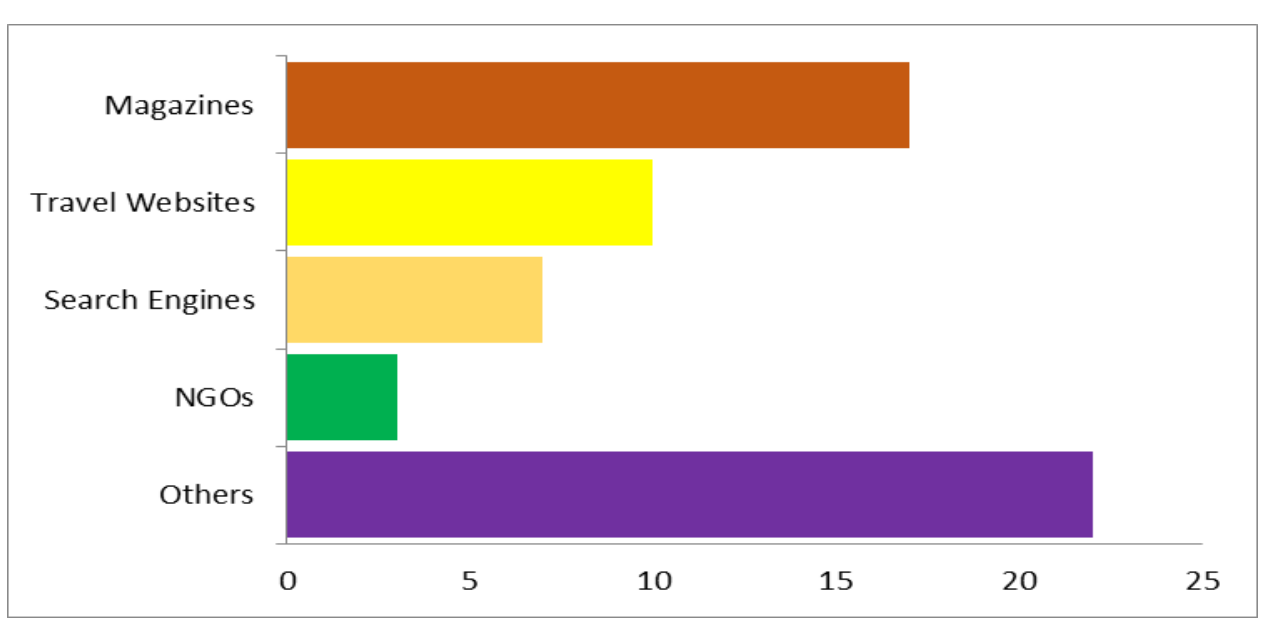

3. The respondents were asked about the destination where they have experienced CBET. The results show that the popular destinations were hill stations in Tamil Nadu, and some places in states of Telangana, Kerala, Karnataka and Andhra.

4. The type of accommodation where more than 40 percent of respondents stayed was Resorts. Next more popular accommodation was preferred as Local Guest Houses and Tented accommodation. This clearly shows that tourists are now changing their interests and likings towards accommodations that provide better feel and culture of local community of the region.

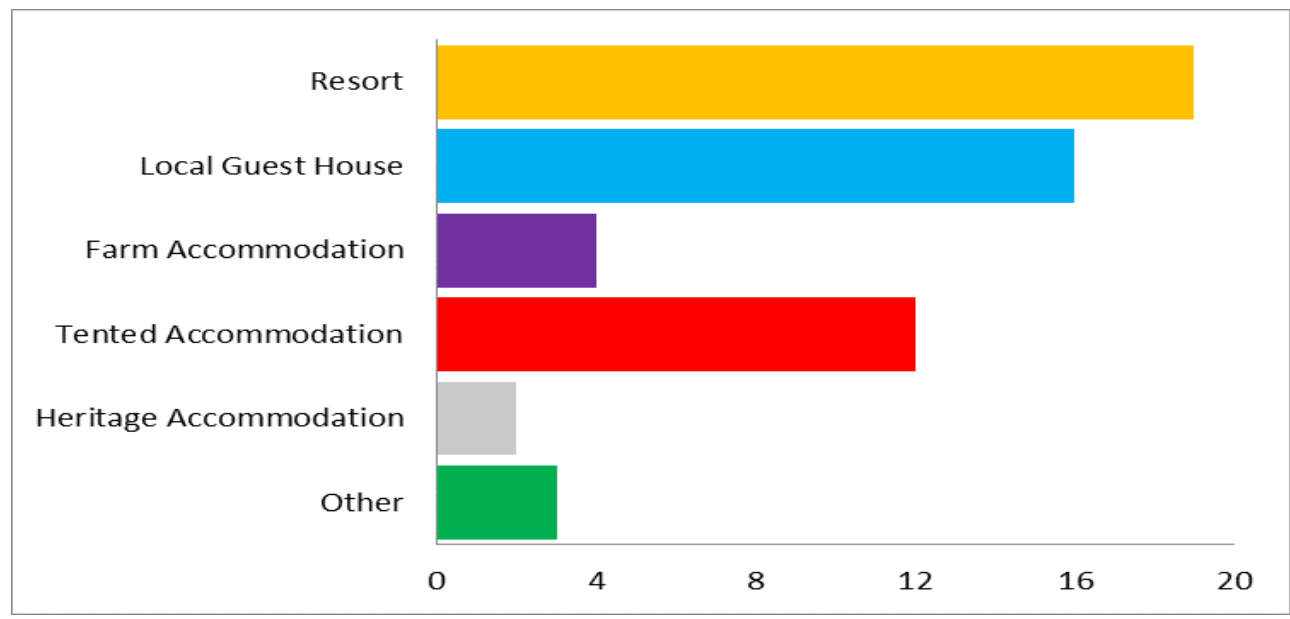

5. More than 80 percent of the respondents were provided meals prepared from locally grown/produced. This clearly depicts that these CBET ventures are not providing the typical hotel menu and using fresh produces and mostly organic produces to prepare and offer their local cuisine.

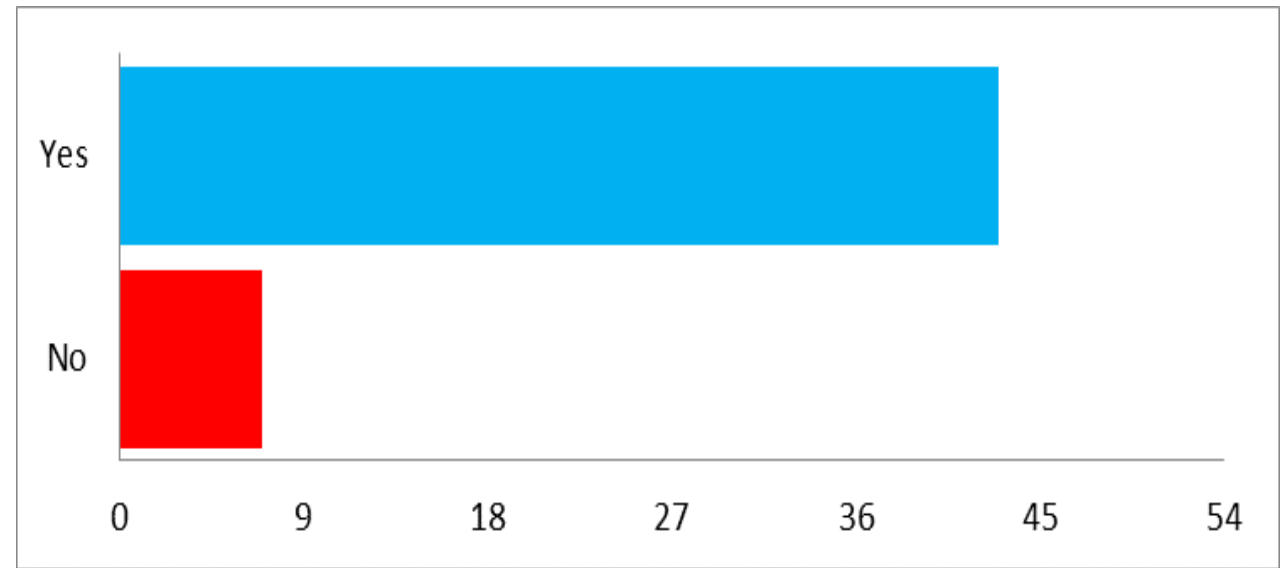

6. When asked about the eco-friendly practices that were adopted at their place of stay, almost 50 percent of respondents said that water harvesting was implemented. Another practice being implemented was solar water heater. 


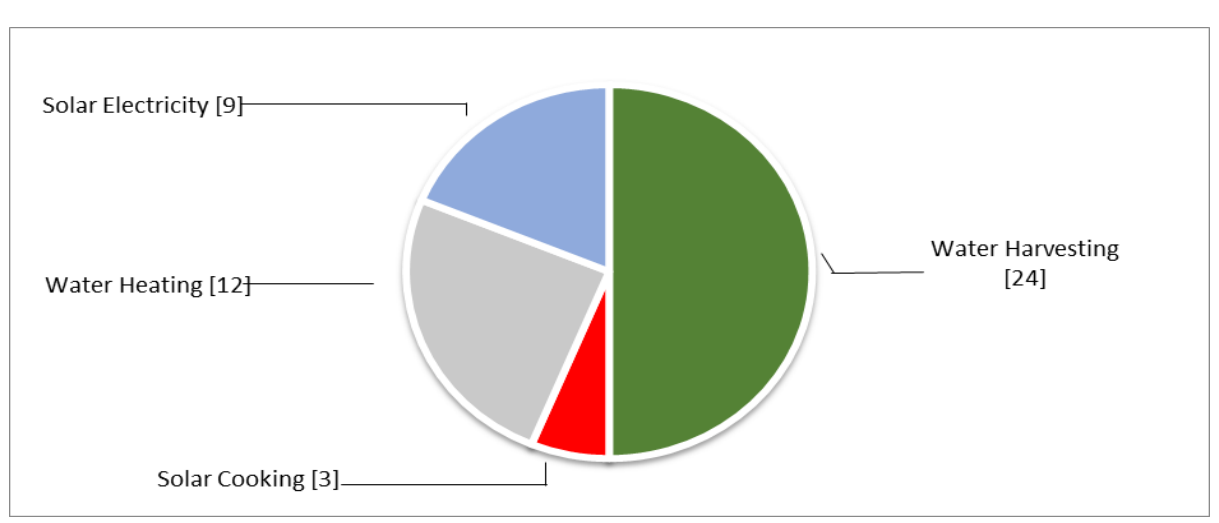

7. Cleanliness, hygiene and sanitation conditions were voted 'Good' at these destinations by more than 60 percent of respondents. Around 20 percent said the conditions were average, whereas 13 percent respondents experienced 'Very Good' conditions.

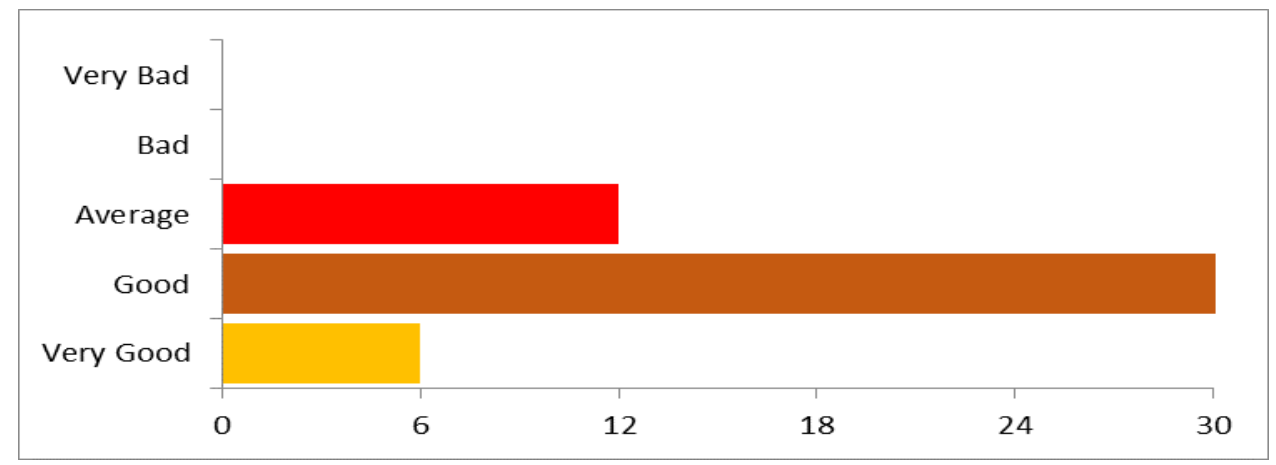

8. Around 60 percent respondents found that the local people were involved in upkeep and maintenance of the Tourist Accommodation and maintenance of the Tourist Accommodation and in Sightseeing activities. This was closely followed by around 40 percent saying locals were actively involved in Farming and Selling of local products as well.

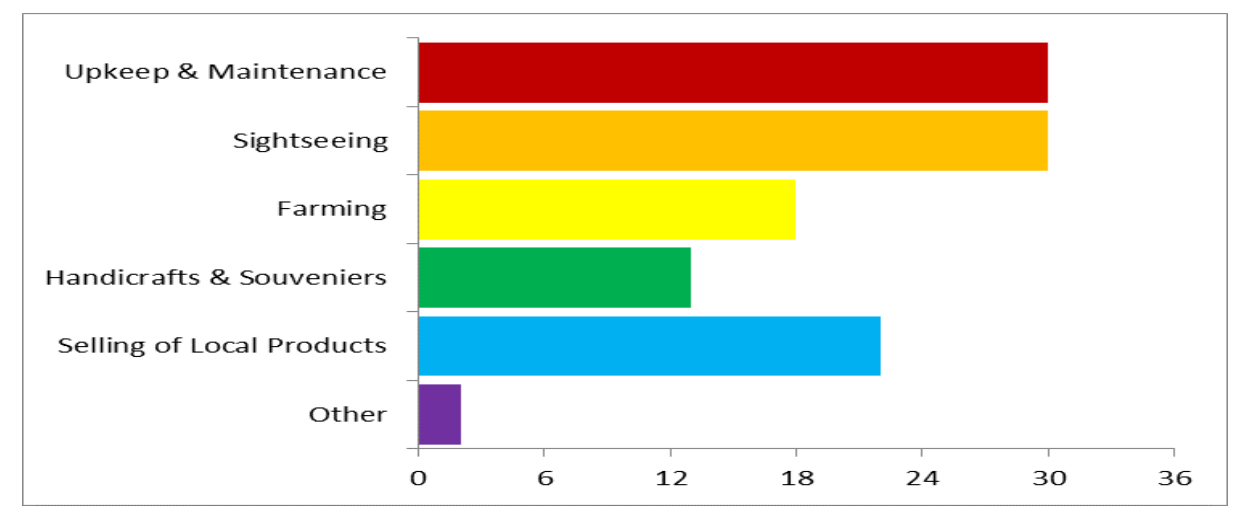

9. On being asked for an opinion on the South Indian states having scope for Community Based Eco Tourism, 65 percent voted for Kerala, closely followed by Tamil Nadu (50 percent), Karnataka, and Andhra were other popular choices.

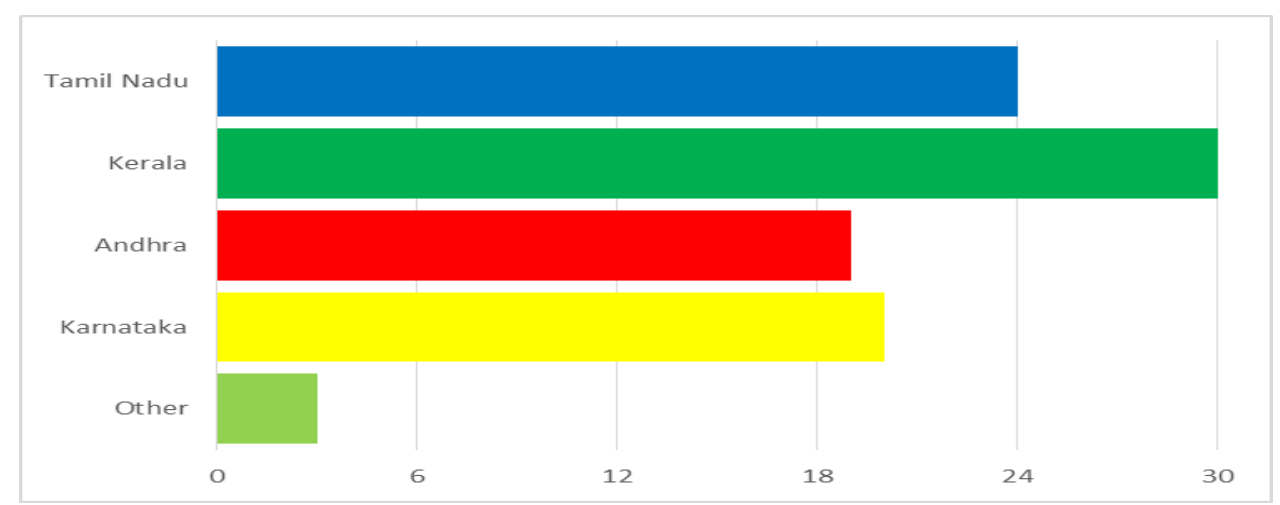


10. On being asked whether Community Based Eco Tourism is benefitting the local community, more than 75 percent answered in affirmative, whereas around 25 percent felt it benefits the local population to some extent.

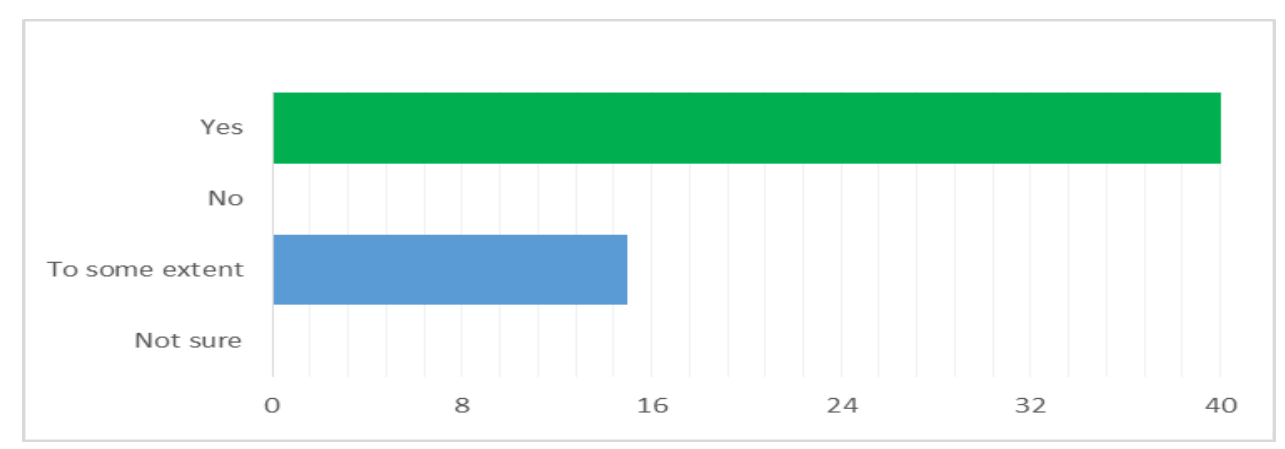

11. Around 50 percent of respondents were aware that Government is initiating steps for developing Community Based Eco Tourism.

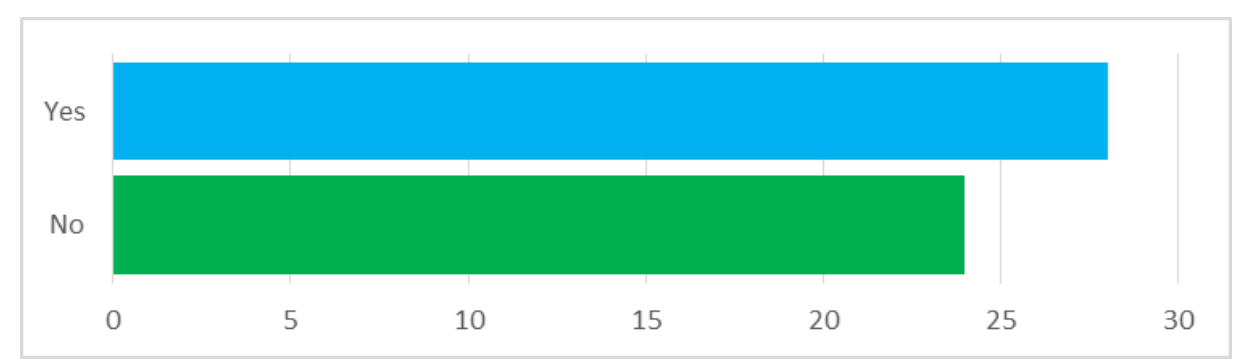

12. More than 95 percent respondents felt tourism products like Community Based Eco Tourism can work well in Tamil nadu.

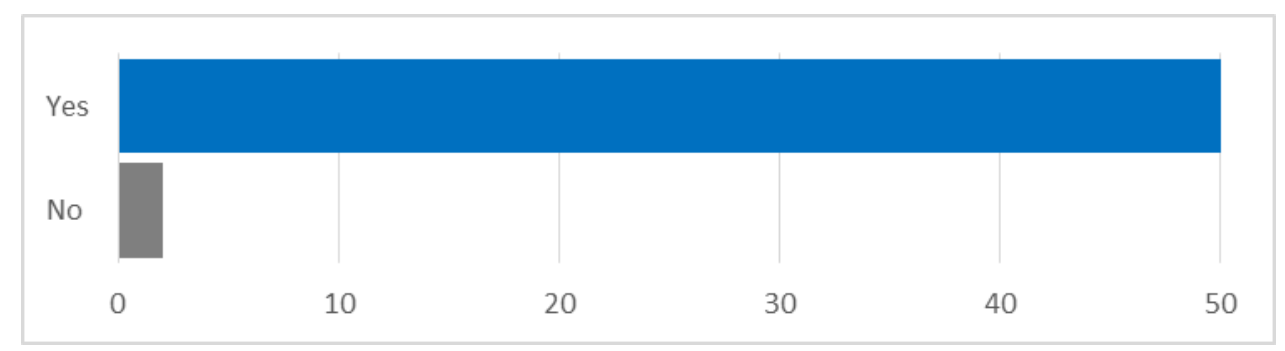

\section{CONCLUSiOn AND SUGgestions}

- India being rich in agriculture and farming, the major population is still living in rural areas where education is still a question. Initiatives to make local people aware and knowledgeable about the significance of tourism and its benefits to local regions can make wonders. Recently Yes Bank Initiatives have come across with a campaign called 'Edge of India' to promote community based tourism in three districts (Bageshwar, Pithoragarh and Ranikhet) of Uttarakhand and (Purulia) West Bengal.

- Many of cities in Tamil Nadu have initiated 'Home Stay', Rural Tourism, Ecotourism, Agritourism, and Farm tourism on the guidelines of Ministry of Tourism, Govt. of India. The new trends are becoming very popular among the youth, as our research show that most of respondents have experienced these types of tourism in one or the other states.

- New Guidelines for Ecotourism Policy of Tamil Nadu (2017), Preamble: Ecotourism is defined as 'responsible travel to natural areas that conserves the environment and improves the well-being of local people'. Such tourism is low impact, educational and conserves the environment while directly benefiting the economic development of local people. It also promotes the nonconsumptive use of wilderness areas, for the benefit of local communities living around and dependent on these fragile landscapes.

- The analysis of the questionnaires indicates that visitors doubt that the income from communitybased ecotourism ventures actually go the real community of the region. Although most respondents agreed that local people were very much involved tourism activities like sightseeing, 
upkeep \& maintenance of the accommodation, manufacturing and selling of handicrafts etc., but the most share of profits or income goes to the stakeholders or private hands.

- Study of literature also indicates that lot of efforts \& initiatives are been taken at International level all over the World. Organizations like UNWTO, WTTC, WWF \& International Ecotourism Society etc., are all involved in developing new concepts, forming policies \& guidelines, initiating $\&$ promoting eco-friendly practices and sustainable tourism for conserving the natural resources for future generations.

- Initiatives like, establishment of Corbett Gram Vikas Simiti (a non-profit organization registered under the Societies Registration Act 1860) at Kala Dhungi (Chhoti Haldwani), for running home stays program like the Bread and Breakfast scheme being encouraged in metros to cater for mass tourism, needs to be encouraged with due incentives by the government to the local communities / villagers.

- Empower local communities to manage ecotourism and generate incentives for conservation through alternate and additional livelihood options since adequate industry setups do not exist in the state except at few places in the planes and masses in the hills are deprived of any employment opportunities/means of livelihood.

- When we talk about tourism contributing to development of the concerned destination, we should ensure our approach is holistic in nature, encompassing dimensions of ethics, equity and justice. It should also encourage local participation, empowerment, destination competitiveness and ultimately destination sustainability.

- Rural communities often have limited understanding of tourism as well as a lack of skills and resources required for the same. Hence, interventions linked to capacity development and strengthening of local institutions is important to channelize benefits from tourism towards those in need of them.

- Typically, the process of tourism development benefits the rich and powerful amongst the local population. To address the concern of bringing about empowerment, it becomes imperative to involve the marginalized sections of the society.

- There are many NGOs working towards reviving the ancient and traditional art forms and craft skills from rural areas. These can be linked to Community Based Eco Tourism and the destination can be promoted as a whole package.

- Capacity building is mostly misinterpreted as infrastructure development. The rampant construction of buildings and lack of collateral development such as skills training carries the danger of the area losing out on its rustic and pristine environs. This scenario does not help in promoting tourism.

\section{REFERENCES}

[1] Armstong R. (2012) An analysis of the conditions for success of community based tourism enterprises, International Centre for Responsible Tourism Occasional Paper OP 21.

[2] Balint, P.J. (2006). Improving Community-based conservation near protected areas: The importance of development variables. Environment Management.Vol.38, No.1, pp.137-148.

[3] Berkes, F. (2007). Community-based conservation in a globalized world. Proceedings of National Academy of Sciences. Vol.104 No.39.

[4] Berkes, F \& Davidson-Hunt, I J. (2010). Innovating through commons use: community-based enterprises. International Journal of the Commons. Vol.4, no 1, pp.1-7.

[5] Bhattacharya A.K., Banerjee S., Saksena V. (2003). Community Based Ecotourism A Case Study of Kerwa Van Vihar National Park Catchments, Bhopal (Madhya Pradesh), Tourism Recreation Research, Vol 28 (1).

[6] Christou, P. \& Saveriades, A. (2010). The Use of Ethnography to Explore Tourist Satisfaction Antecedents. Tourismos, Vol.5, No.1, pp.89-100.

[7] Development IIED, 2006.

[8] Ecotourism Society of India (EcoSoc). (2005). Memorandum of Association and Rules, Govt. of Himatchal Pradesh. 
[9] Effective Community Based Tourism: A Best Practice Manual, A Best Practice Manual, June 2010. Equations, Can Tourism Transform? Community-based Tourism Initiatives in India-Equations 2008. Ecotourism Manual (2009); Wildlife Institute of India.

[10] Guidelines for Ecotourism in and Around Protected Areas; 2011, Ministry of Environment and Forests, India.

[11] Gangotia, A. (2013). Home Stay Scheme in Himatchal Pradesh : A Successful Story of Community Based Tourism Initiatives, Global Research Analysis International, Volume:2, Issue : 2, ISSN No.2277-8160.

[12] Goodwin, H. 2002). Local Community Involvement in Tourism around National Parks: Opportunities and Constraints in Special Issue of Current Issues in Tourism 5 (3\&4).

[13] Goodwin, H, Kent I, Parker K, Walpole, M, Tourism, Conservation and Sustainable.

[14] Goodwin, H. \& Santilli, H. (2009). Community - Based Tourism: A Success? ICRT Occasional Paper 11.

[15] Kayat, K. (2010). The Nature of Cultural Contribution Of a Community - Based Homestay Programme. Tourismos, Vol.5, No.2, pp.145-159.

[16] Kibicho, W. (2008). Community-based tourism: A factor - cluster segmentation approach. Journal of Sustainable Tourism, Vol.16, No.2, pp.211-231.

[17] Lepp, A. (2007). Residents Attitudes towards Tourism in Bigodi Village, Uganda. Tourism Management, Vol.28, No.3, pp.876-885.

[18] Lopez-Guzman 1, T, Sanchez-Canizares, S and Pavon, V.(2011) Community - Based Tourism In Developing Countries : A Case Study, An International Multidisciplinary Journal Of Tourism, volume 6, Number 1, pp.69-84.

[19] Okazaki, E. (2008) A Community-Based Tourism Model. Its Conception and Use. Journal of Sustainable Tourism, Vol.16, No.5, pp.511-529.

[20] Pimbert, M.P. \& Pretty, J.N. (1997) Diversity and sustainability in community based conservation. Paper presented at UNESCO-IIPA regional workshop on Community-based Conservation, India.

[21] Scheyvens Regina. (1999) Ecotourism and the empowerment of local communities - Tourism Management 20 (1999) 245-24.

[22] Sharma P., Kamboj R. (2012). Responsible Tourism: Trends in Indian Tourism Sector, International Journal of Trends in Tourism Management, Volume 1 issue 6.

[23] Simpson, M.C. (2008). Community Benefit Tourism Initiatives - A Conceptual Oxymoron? Tourism Management, Vol.29, No.1, pp.1-18.

[24] Strategic Initiatives \& Government Advisory Team - Emerging Dimensions \& New Products in Indigenous Tourism, 2012.

[25] Tourism Today, The Journal Of The College Of Tourism And Hotel Management Number 4, Autumn 2004.

[26] Walpole M J, Goodwin HJ. (2001). Local attitudes towards conservation and tourism around Komodo National Park, Indonesia Environmental Conservation 28 (2): 160-166.

Citation: A. Apsara Saleth Mary. "Community - Based Ecotourism: Trends and Prospects in Tamil Nadu". International Journal of Research in Tourism and Hospitality (IJRTH), vol 5, no. 2, 2019, pp. 25-35. doi: http://dx.doi.org/10.20431/2455-0043.0502004.

Copyright: (C) 2019 Authors. This is an open-access article distributed under the terms of the Creative Commons Attribution License, which permits unrestricted use, distribution, and reproduction in any medium, provided the original author and source are credited. 